\title{
Evaluasi Desa Tangguh Bencana dalam Perspektif Formatif dan Reflektif Ketangguhan Masyarakat
}

\author{
Kartika Purwaningtyas \\ Universitas Katolik Parahyangan, Jalan Ciumbuleuit No. 94, \\ Hegarmanah Kecamatan Cidadap, Kota Bandung \\ astatika@ymail.com, Telp. +6282325995342
}

\begin{abstract}
Abstrak
Kompleksitas dari konsep ketangguhan masyarakat berkembang seiring dengan perubahan yang terjadi secara dinamis. Pada hakikatnya, ketangguhan masyarakat adalah kemampuan masyarakat/komunitas/kelompok dalam merespon perubahan yang terjadi akibat berbagai kondisi eksternal salah satunya bencana alam. Desa tangguh bencana merupakan salah satu upaya dalam membangun ketangguhan masyarakat dalam menghadapi potensi bencana yang dihadapi di Indonesia. Dalam pengukuran ketangguhan masyarakat telah banyak dikembangkan dengan berbagai pendekatan diantaranya pada pendekatan normatif dan reflektif. Melalui studi deksriptif dengan kajian pustaka dengan bertujuan untuk melakukan evaluasi terhadap Desa Tangguh Bencana dalam perspektif normatif dan Reflektif. Dalam Desa Tanggung Bencana dibentuk atas empat dimensi dalam yaitu regulasi, kelembagaan, pendanaan, pengembangan kapasitas dan penanggulan bencana. Hasil telaah menunjukan bahwa pada indikator terkait modal sosial dalam hal ini seperti pelatihan dan pemberdayaan masyarakat menjadi bagian dalam skala normatif atau sebagai faktor yang membentuk adanya ketangguhan masyarakat dalam Desa Tangguh Bencana. Selanjutnya instrumen hasil dalam Desa Tangguh Bencana diantaranya sistem peringatan dini, peta dan analisis risiko serta mitigasi struktural sebagai indikator petunjuk atau reflektif yang menggambarkan bagaimana ketangguhan masyarakat dalam menghadapi kondisi bencana di kemudian hari. Dominasi skala reflektif dalam Desa Tangguh Bencana sehingga perlu kedepannya didorong untuk memperkuat aspek normatif yang berasal dari internal komunitas/kelompok masyarakat. Keterbatasan analisis dan pembahasan dalam artikel ini perlu dikembangkan dalam kajian selanjutnya untuk melihat sejauh mana efektivitas dari Desa Tangguh bencana dalam perspektif ketangguhan masyarakat dan mengukur masing - masing kelompok normatif dan reflektif pada dimensi Desa Tangguh bencana serta kontribusi antar indikator dalam membentuk ketangguhan masyarakat sehingga proses pemberdayaan berjalan secara maksimal.
\end{abstract}

Kata Kunci : Desa Tangguh Bencana, Indikator Reflektif, Indikator Normatif

\section{Abstract}

The complexity of the community resilience develops with the change dynamically. Community resilience is about the community's ability to respond to changes due to various external conditions such as disasters. Disaster Resilient Village (Desa Tangguh Bencana) is an Indonesian Government Programme for build community resilience facing potential disasters. Measuring community 
resilience has many approaches, including normative and reflective approaches, through a descriptive study with a literature review to evaluate the Disaster Resilient Villages (Desa Tangguh Bencana) from normative and reflective perspectives. The Programme of Disaster Resilience villages formed into four are regulatory, institutional, funding, and capacity building and disaster management. The analysis shows that the indicators related to social capital, in this case, such as training and community empowerment that are part of a normative scale or as a factor that shapes community resilience. Furthermore, the instruments in disaster-resilient villages such as early warning systems, maps and risk analysis, and structural mitigation are indicative or reflective indicators that describe how community resilience is in facing disaster conditions in the future. The dominance of reflective indicators over normative indicated that in the future, the normative indicator, which improves the capacity of the community facing the changes, causes disaster. The article's limitation needs to explore and develop in further study to see the effectiveness of disaster resilience villages from normative and reflective scale and the contribution of these indicators in shaping the community resilience.

\section{Keywords : Disaster Resilience Village, Formatif Indicator, Normatif Indicator}

\section{PENDAHULUAN}

Individu memiliki dua peran yaitu sebagai bagian dalam makhluk hidup yang berhubungan dengan makhluk hidup lain (seperti tumbuhan, hewan dan kondisi alam) dan kelompok masyarakat. Tanpa disadari peran yang melekat pada individu berimbas terhadap bagaimana kemampuan dalam menghadapi berbagai berbagai potensi tantangan yang berasal dari internal maupun eksternal atau lingkungan sekitar. Tantangan eksternal yang dihadapi salah satu penyebabnya karena adanya perubahan yang terjadi diantaranya kondisi alam akibat perubahan iklim, disrupsi ekonomi serta kondisi politik dan keamanan. Menjadi bagian dalam sebuah komunitas atau kelompok masyarakat merupakan peran individu yang tidak terelakan. Disrupsi yang dihadapi oleh individu tersebut dapat terjadi pula pada komunitas seperti bencana alam, perang, wabah penyakit dan tantangan eksternal lainnya. Bagaimana individu atau masyarakat merespon terhadap berbagai tekanan dan tantangan yang dihadapi secara konsep dikenal dengan istilah ketangguhan masyarakat (Community Resilience). Ketangguhan masyarakat adalah pengembangan dan keterlibatan berbagai sumber daya yang dimiliki oleh masyarakat untuk dapat berkembang dalam lingkungan dikarenakan 


\section{JURNAL PEMBERDAYAAN MASYARAKAT $\mid 62$ \\ Volume 9 No. 1 Tahun 2021 ISSN: 2355-}

perubahan, ketidakpastian dan berbagai tantangan yang bermunculan ${ }^{1}$. Ketangguhan tidak hanya memfokuskan pada upaya pengendalian yang dihadapi oleh seorang individu yang mampu mempengaruhi komunitas, namun melihat bagaimana kemampuan individu dan komunitas bertahan terhadap berbagai tantangan yang dihadapi ${ }^{2}$. Kemampuan komunitas menghadapi berbagai persoalan tanpa disadari tumbuh ketika menghadapi sebuah kondisi yang diakibatkan adanya perubahan atau gangguan yang dialaminya. Perubahan yang terjadi dalam kelompok masyarakat atau komunitas menyebabkan ketangguhan masyarakat bersifat dinamis karena masyarakat menyesuaikan kondis yang ada $^{3}$, sehingga dapat mempertahankan infrastruktur sosial yang dimilik ${ }^{4}$. Membangun ketangguhan masyarakat berarti meningkatkan kemampuan komunitas untuk berkembang dalam lingkungan yang dinamis yang diindikasikan pada kondisi ketidakpastian akibat perubahan yang terjadi ${ }^{5}$.

Berbagai kajian dilakukan untuk mengidentifikasikan dan mengukur bagaimana ketangguhan masyarakat terbentuk salah satunya dilihat pada faktor yang mempromosikan pertumbuhan ketahanan masyarakat dan tingkat ketangguhan dengan didasarkan dimensi lokasi dan waktu yang berbeda ${ }^{6}$. Mengukur ketangguhan masyarakat dapat dilihat dengan merujuk pada dimensi sumber daya yang dimiliki dalam komunitas, pengembangan sumber daya komunitas, keterlibatan atau pengaruh atas sumber daya, tindakan kolektif dalam komunitas yang dilakukan oleh anggota yang aktif dan keadilan di dalam komunitas $^{7}$.

\footnotetext{
${ }^{1}$ Magis, K. (2010a). Community resilience: An indicator of social sustainability. Society and Natural Resources. https://doi.org/10.1080/08941920903305674

${ }^{2}$ Ahmed, R., Seedat, M., Van Niekerk, A., \& Bulbulia, S. (2004). Discerning community resilience in disadvantaged communities in the context of violence and injury prevention. South African Journal of Psychology, 34(3), 386-408

ibid

${ }^{3}$ Fawcett, S. B., Paine-Andrews, A., Francisco, V. T., Schultz, J. A., Richter, K. P., Lewis, R. K., Williams, E. L., Harris, K. J., Berkley, J. Y., Fisher, J. L., \& Lopez, C. M. (1995). Using empowerment theory in collaborative partnerships for community health and development. American Journal of Community Psychology, 23(5), 677-697

${ }^{4}$ Adger, W. N. (2000). Social and ecological resilience: Are they related? Progress in Human Geography, 24(3), 347-364

5 ibid

${ }^{6}$ Lindberg, K., \& Swearingen, T. (2020). A Reflective Thrive-Oriented Community Resilience Scale. American Journal of Community Psychology, 65(3-4), 467-478. https://doi.org/10.1002/ajcp.12416
}

7 Magis, K. (2010b). Community resilience: An indicator of social sustainability. Society and 


\section{JURNAL PEMBERDAYAAN MASYARAKAT 63 \\ Volume 9 No. 1 Tahun 2021 ISSN: 2355-}

Secara praktis, kerangka ketangguhan masyarakat khususnya dalam menghadapi kondisi bencana telah dikembangkan secara internasional diantaranya dengan Yokohama Strategy (1994), Hyogo Framework (2005 - 2015) dan Sendai Framework (2015 - 2030). Hyogo Framework oleh Persatuan Bangsa - Bangsa dengan menitikberatkan pada upaya dan prioritas tindakan yang dilakukan oleh pemangku kepentingan yaitu (i) Memastikan pengurangan risiko bencana sebagai prioritas nasional dan lokal dengan pengembangan kelembagaan yang kuat; (ii) mengidentifikasi, menilai dan memantau risiko bencana dan meningkatkan peringatan dini; (iii) Memaksimalkan pengetahuan, inovasi dan pendidikan untuk membangun budaya keselamatan dan ketangguhan masyarakat pada semua tingkatan; (iv) Mengurangi faktor risiko atas kondisi kahar; (v) memperkuat kesiapsiagaan bencana untuk memberikan respon yang efektif di semua tingkatan. Kerangka kerja Hyogo mencatat bahwa dalam pengurangan risiko membutuhkan keterlibatan dan kemitraan seluruh lapisan masyarakat. Selain itu diperlukan pemberdayaan dan partisipasi inklusif yang mudah diakses dan non diskriminatif.

8 . Berakhirnya prioritas kerangka kerja Hyogo tergantikan prioritas pada kerangka kerja Sendai yang memfokuskan diantaranya (i) Memahami risiko bencana; (ii) menguatkan tata kelola risiko bencana untuk mengelola risiko bencana; (iii) menginvestasikan pengurangan risiko bencana agar menumbuhkan ketangguhan masyarakat; (iv) meningkatkan kesiapsiagaan bencana untuk respon yang efektif. Prioritas dalam kerangka kerja dalam ketangguhan masyarakat menghadapi bencana yang tertuang dalam kerangka kerja Hyogo dan Sendai menggambarkan bahwa ketangguhan masyarakat menjadi aspek utama dalam menghadapi berbagai tantangan eksternal. Kerangka kerja Bencana secara internasional juga dikembangkan oleh Pemerintah Indonesia untuk mengidentifikasikan dan menentukan kriteria untuk membentuk Desa tangguh bencana sebagaimana diatur

Natural Resources, 23(5), 401-416. https://doi.org/10.1080/08941920903305674

${ }^{8}$ United Nations. (2005). International Strategy for Disaster Reduction Hyogo Framework for Action 2005-2015: Building the Resilience of Nations. World Conference on Disaster Reduction (A/CONF.206/6), 25.

Zautra, A., Hall, J., \& Murray, K. (2008). Community Development and Community Resilience: An Integrative Approach. Community Development, 39(3), 130-147. https://doi.org/10.1080/15575330809489673 


\section{JURNAL PEMBERDAYAAN MASYARAKAT $\mid 64$ \\ Volume 9 No. 1 Tahun 2021 ISSN: 2355-}

dalam Peraturan Kepala Badan Nasional Perencanaan penanggulangan Bencana Nomor 1 Tahun 2012 tentang Pedoman umum Desa Tangguh Bencana.

Pembentukan Desa Tangguh Bencana merupakan upaya jawaban Pemerintah untuk mengatasi berbagai tantangan eksternal yang dihadapi oleh masyarakat yang ada di desa khususnya dalam menghadapi Bencana alam yang dialami. Bahwa masyarakat dan perkembangan lingkungan yang dinamis mengakibatkan pengukuran bagaimana ketangguhan masyarakat dalam menghadapi berbagai tantangan internal dan eksternal memiliki kompleksitas dalam pengukurannya. Berbagai pendekatan dan skala pengukuran digunakan untuk menguji ketangguhan masyarakat terhadap berbagai tantangan eksternal. Pengukuran ketangguhan masyarakat yang dikelompokan pada skala reflektif dan normatif. Dimana skala reflektif melihat pada bagaimana efek yang diakibatkan oleh ketangguhan masyarakat. Sementara skala reflektif berarti melihat indikator penyebab terhadap variabel laten yang ingin dilihat. Pengembangan terhadap pengukuran baik secara reflektif maupun normatif perlu ditelaah secara mendalam, merujuk pada uraian diatas artikel ini bertujuan untuk melakukan telaah terhadap evaluasi terhadap Indikator Desa Tangguh Bencana dalam perspektif reflektif dan normatif.

\section{METODE PENELITIAN}

Untuk melakukan telaah terhadap bagaimana kriteria dalam Desa Tangguh Bencana dalam perspektif reflektif dan normatif dengan pendekatan deskriptif secara sistematik kajian pustaka yang akan menguraikan stuktur dan tujuan atas hasil pengkajian pustaka yang dilakukan secara logis yang kemudikan dilakukan pembahasan secara komprehensif dari telaah terhadap berbagai sumber artikel ilmiah, dokumen dan informasi tentang permasalahan yang dipaparkan. Melalui berbagai artikel ilmiah tentang ketangguhan masyarakat dan metode pengukurannya, dokumen desa tanggung bencana dan informasi yang diperolah dari sumber sekunder seperti Laporan Tahunan Desa Tangguh Bencana dan Media Pemberitaan Cetak maupun Online digunakan dalam melakukan analisa

\footnotetext{
9 Wee, B. Van, \& Banister, D. (2016). How to Write a Literature Review Paper? Transport Reviews, 36(2), 278-288. https://doi.org/10.1080/01441647.2015.1065456
} 
dan telaah secara komprehensif terhadap Indikator Desa Tangguh Bencana dalam pendekatan skala reflektif maupun skala normatif.

\section{Indikator Ketangguhan Masyarakat}

Fokus dari ketangguhan masyarakat tentang bagaimana kapasitas kelompok/komunitas/masyarakat dalam menghadapi berbagai tantangan. Perubahan yang dihadapi oleh masyarakat dapat berupa hal yang bersifat positif maupun negatif. Namun sebagian besar pendapat mengaitkan ketangguhan masyarakat terhadap perubahan yang bersifat negatif seperti kondisi bencana alam yang dihadapi oleh masyarakat. Berkes dan Seixas dalam bahwa ketangguhan masyarakat didalamnya menyangkut aspek bagaimana masyarakat belajar terhadap perubahan dan ketidakpastian, memelihara keragaman untuk reorganisasi dan pembaharuan, melakukan inovasi dengan menggabungkan berbagai pengetahuan yang dimiliki serta menciptakan peluang ${ }^{10}$.

Ketangguhan masyarakat melihat bagaimana sumber daya secara internal yang dimiliki oleh kelompok untuk merespon perubahan yang dihadapi dimana sumber daya tersebut dapat berupa secara ekonomi, sosial, cultural, alam bahkan secara politik. Kemampuan secara ekonomi, sosial dan lingkungan menjadi satu kesatuan yang terikat dalam konsep ketangguhan. Ketiga pilar ini dipandang sebagai dasar untuk memahami proses pembentukan ketangguhan pada tingkat komunitas ${ }^{11}$.

Tabel 1. Community Resilience dan Indikator Global

\begin{tabular}{|c|c|c|}
\hline $\begin{array}{l}\text { Community } \\
\text { Resilience }\end{array}$ & Strong Capital & Weak Capital \\
\hline Economic Capital & \begin{tabular}{lll} 
- & \multicolumn{2}{l}{ Economic Well Being } \\
- & Pendapatan & yang \\
& beragam & \\
- & Tidak & tergantung \\
& terhadap & sumber \\
& pendanaan dari luar
\end{tabular} & $\begin{array}{l}\text { - } \text { Kemiskinan } \\
\text { - Infrastruktur yang } \\
\text { buruk } \\
\text { - Ketergantungan } \\
\text { berlebih terhadap } \\
\text { pertanian atau produks }\end{array}$ \\
\hline
\end{tabular}

\footnotetext{
${ }^{10}$ Magis, K. (2010a). Community resilience: An indicator of social sustainability. Society and Natural Resources. https://doi.org/10.1080/08941920903305674

${ }^{11}$ Lyth, A. (2015). Community resilience and environmental transitions. In Australasian Journal of Environmental Management (Vol. 22, Issue 3). https://doi.org/10.1080/14486563.2015.1023691
} 


\begin{tabular}{|c|c|c|}
\hline & - Diversifikasi usaha & $\begin{array}{l}\text { primer } \\
\text { - Impor terhadap bahan } \\
\text { makanan/ barang }\end{array}$ \\
\hline Social Capital & 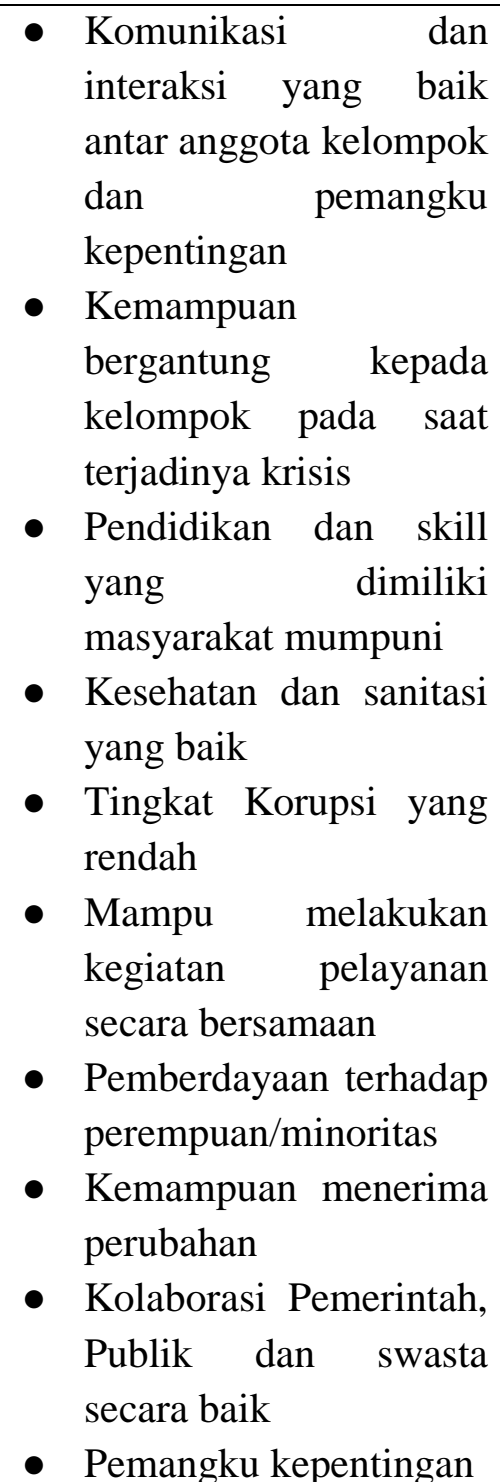 & 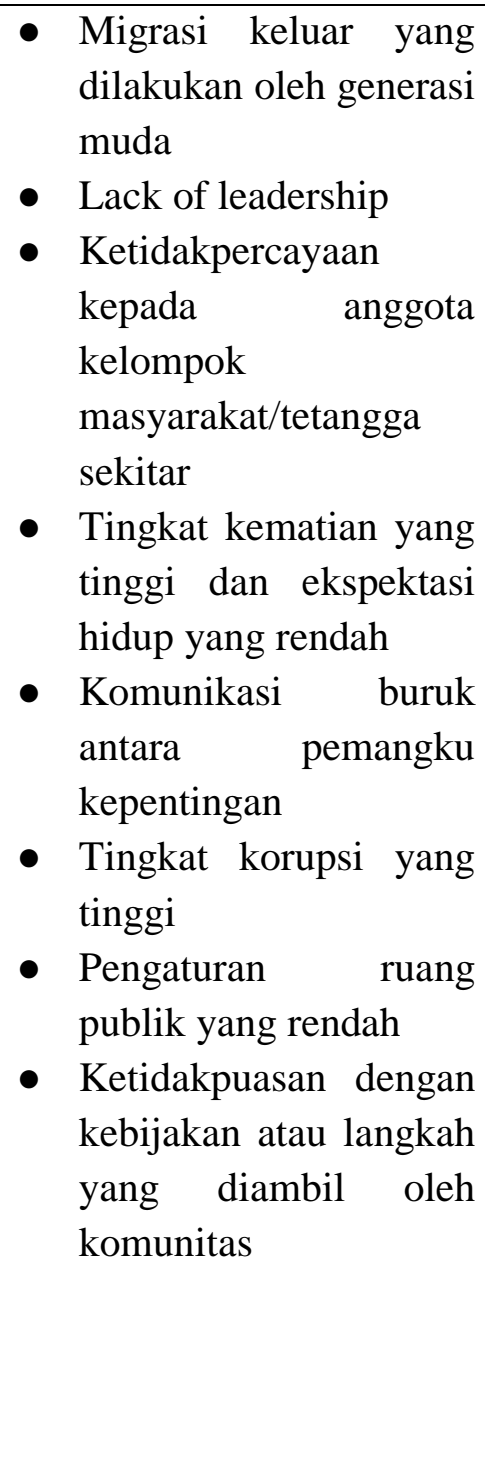 \\
\hline $\begin{array}{c}\text { Kemampuan } \\
\text { Lingkungan/Environ } \\
\text { mental Capital }\end{array}$ & $\begin{array}{ll}\text { - } & \text { Kualitas dan } \\
\text { ketersediaan air yang } \\
\text { cukup dan baik }\end{array}$ & $\begin{array}{l}\text { - } \text { Degradasi tanah } \\
\text { - Kualitas air yang buruk } \\
\text { - Kekeringan } \\
\text { - Penggunaan karbon } \\
\text { tinggi } \\
\text { - Penggunaan minyak } \\
\text { dan ketidakmampuan } \\
\text { komunitas } \\
\text { memanfaatkan } \\
\text { pengganti/sumber } \\
\text { lainnya lahan } \\
\text { - Penggunaan }\end{array}$ \\
\hline
\end{tabular}




\begin{tabular}{|l|lll|}
\hline & $\begin{array}{l}\text { dimanfaatkan secara } \\
\text { baik }\end{array}$ & $\begin{array}{l}\text { pertanian } \\
\text { berlebihan }\end{array}$ & secara \\
\hline
\end{tabular}

Sumber : (Cutter et al., 2008; Magis, 2010a)

Ketiga pilar ekonomi, sosial dan lingkungan dalam tingkat komunitas menjadi bagian dalam sebuah proses yang memanfaatkan jaringan sosial dan sumber daya secara maksimal pada saat dibutuhkan. Pada sumber daya secara ekonomi memperhatikan aspek diantaranya sumber daya, proses distribusi secara adil dan keberagaman atas sumber daya ekonomi. Dalam modal sosial (social capital) dapat diartikan sebagai konektivitas sosial dalam sebuah komunitas dimana didalamnya menyangkut nilai sosial (norma), jaringan/networking dan kepercayaan yang diinternalisasi dalam jangka waktu yang lama yang tanpa disadari sebagai nilai yang diyakini untuk generasi saat ini dan yang akan datang $^{12}$.

Lebih lanjut peran individu dalam komunitas/masyarakat menjadi faktor penting tidak terpisahkan sebagai pembentuk ketangguhan masyarakat. Partisipasi aktif anggota akan mampu mempengaruhi berbagai sikap dan keputusan yang diambil dalam komunitas tersebut sehingga mampu memberikan dampak baik secara ekonomi, sosial dan lingkungan serta dalam pemanfaatan kapasitas yang dimiliki masyarakat ${ }^{13}$. Kemampuan memahami komunitas, kesadaran kritis dari anggota kelompok tentang penyebab masalah dan kemungkinan perubahan yang akan dihadapi serta kepemimpinan maka faktor individual dan kelompok dapat menjadi faktor yang mendukung pemberdayaan didalam masyarakat ${ }^{14}$. Partisipasi dan pemberdayaan masyarakat tidak dapat berjalan secara efektif apabila tidak ada kerjasama melalui tindakan kolektif pemangku kepentingan untuk mencapai tujuan yang telah disepakati bersama ${ }^{15}$.

${ }^{12}$ ibid

Morrow, E., \& Scorgie-Porter, L. (2017). Bowling Alone: The Collapse and Revival of American Community. In Bowling Alone: The Collapse and Revival of American Community. https://doi.org/10.4324/9781912282319

${ }^{13}$ Lindberg, K., \& Swearingen, T. (2020). A Reflective Thrive-Oriented Community Resilience Scale. American Journal of Community Psychology, 65(3-4), 467-478. https://doi.org/10.1002/ajcp.12416

Magis, K. (2010b). Community resilience: An indicator of social sustainability. Society and Natural Resources, 23(5), 401-416. https://doi.org/10.1080/08941920903305674

${ }^{14}$ Fawcett, S. B., Paine-Andrews, A., Francisco, V. T., Schultz, J. A., Richter, K. P., Lewis, R. K., Williams, E. L., Harris, K. J., Berkley, J. Y., Fisher, J. L., \& Lopez, C. M. (1995). Using empowerment theory in collaborative partnerships for community health and development. American Journal of Community Psychology, 23(5), 677-697. https://doi.org/10.1007/BF02506987

${ }^{15}$ Gamson, W. A., \& Tarrow, S. (1999). Power in Movement: Social Movements and Contentious Politics. Contemporary Sociology. https://doi.org/10.2307/2654187

Magis, K. (2010b). Community resilience: An indicator of social sustainability. Society and Natural Resources, 23(5), 401-416. https://doi.org/10.1080/08941920903305674 
Dalam ketangguhan masyarakat, aspek ketangguhan dari individu, sosial kohesi dan kesejahteraan masyarakat sebagai bagian dalam indikator reflektif ${ }^{16}$. Sisi kepemimpinan yang efektif dipandang sebagai langkah formatif hal tersebut dikarenakan dengan kepemimpinan yang efektif akan mampu menjadikan komunitasnya berkembang dalam menghadapi berbagai perubahan dan tantangan secara eksternal ${ }^{17}$. Sebagai bagian dalam tujuan sosial, pengukuran terhadap ketangguhan komunitas/masyarakat menentukan bagaimana konsistensi masing masing indikator atau faktor pembentuk atau yang terbentuk dari ketahanan masyarakat itu sendiri ketika menghadapi sebuah perubahan.

\section{HASIL DAN PEMBAHASAN}

\section{Bagaimana Indikator Desa Tangguh Bencana dalam Perspektif Skala Reflektif dan Normatif?}

Indonesia berada dalam kawasan cincin api pasifik atau dikenal Ring of Fire yang mengakibatkan potensi letusan gunung berapi aktif dan gempa bumi tidak dapat dihindarkan. Kemampuan secara mandiri untuk beradaptasi dan menghadapi berbagai ancaman bencana serta memulihkan diri secara cepat dan tepat akibat bencana yang ditimbulkan diperlukan pada tingkatan Desa. Upaya perlindungan dan pengurangan risiko terhadap bencana dengan berbasis masyarakat dilakukan pemerintah dengan membentuk dan mengembangkan Desa Tangguh Bencana. Penanganan dan pengurangan risiko berbasis komunitas dalam pengembangan Desa Tangguh Bencana juga dipadukan pada tahapan perencanaan dan praktik pembangunan secara reguler. Pengurangan Risiko Bencana Berbasis Masyarakat merupakan upaya pengelolaan risiko bencana yang melibatkan secara aktif masyarakat yang berisiko dalam mengkaji, menganalisis, menangani, memantau dan dan mengevaluasi risiko bencana untuk mengurangi kerentanan meningkatkan kemampuannya ${ }^{18}$.

Membangun ketangguhan masyarakat melalui program Desa Tangguh Bencana menempatkan masyarakat sebagai subjek sehingga akan mampu membentuk struktur dalam tatanan masyarakat sehingga keberlanjutan dari program dapat berlangsung. Badan Nasional Penanggulangan bencana (2012) menyebutkan terdapat beberapa prinsip dikembangkan dalam Desa Tangguh bencana diantaranya :

a) Bencana sebagai urusan bersama

b) Pengembangan harus didasarkan pada pengurangan risiko bencana

c) Pemenuhan hak masyarakat

\footnotetext{
${ }^{16}$ Lindberg, K., \& Swearingen, T. (2020). A Reflective Thrive-Oriented Community Resilience Scale. American Journal of Community Psychology, 65(3-4), 467-478.

${ }^{18}$ Badan Nasional Penanggulangan Bencana. (2012). Pedoman Umum Desa Tangguh Bencana.
} 
d) Masyarakat sebagai pelaku utama untuk mewujudkan keberhasilan pengembangan Desa Tangguh Bencana

e) Dilakukan secara partisipatoris

f) Mobilisasi sumber daya lokal

g) Inklusif, berlandaskan kemanusiaan;

h) Keadilan dan kesetaraan gender

i) Keberpihakan pada kelompok rentan

j) Transparansi dan akuntabilitas

k) Kemitraan

1) Multi ancaman

m) Otonomi dan desentralisasi pemerintahan

n) Terintegrasi dengan pembangunan berkelanjutan

o) Diselenggarakan secara lintas sektor.

Tabel. 2 Aspek dan Indikator Desa Tangguh Bencana

\begin{tabular}{|c|c|}
\hline Dimensi & Indikator \\
\hline Legislasi & $\begin{array}{lllll}\text { Kebijakan desa tentang Pengurangan resiko } \\
\text { Bencana }\end{array}$ \\
\hline \multirow[t]{3}{*}{ Perencanaan } & Terbentuk Forum Pengurangan Resiko Bencana \\
\hline & Relawan Penanggulangan Bencana \\
\hline & Kerjasama Pemangku Kepentingan/Stakeholders \\
\hline \multirow[t]{2}{*}{ Pendanaan } & Ketersediaan Dana Tanggap Darurat \\
\hline & $\begin{array}{l}\text { Ketersediaan Dana dalam rangka Pengurangan } \\
\text { Resiko Bencana }\end{array}$ \\
\hline \multirow[t]{7}{*}{ Pengembangan Kapasitas } & Pelatihan untuk perangkat pemerintah desa \\
\hline & $\begin{array}{l}\text { Pelatihan untuk tim relawan } \\
\text { Pelatihan untuk warga desa }\end{array}$ \\
\hline & Pelibatan/Partisipasi Warga Desa \\
\hline & Pelibatan Perempuan dalam tim relawan \\
\hline & Pembuatan Peta dan analisis Risiko \\
\hline & Peta dan Jalur Evakuasi dan tempat pengungsian \\
\hline & Sistem Peringatan Dini \\
\hline \multirow{5}{*}{$\begin{array}{l}\text { Penyelenggaraan } \\
\text { Penanggulangan Bencana }\end{array}$} & Pelaksanaan Mitigasi Struktural \\
\hline & $\begin{array}{l}\text { Pola ketahanan ekonomi untuk mengurangi } \\
\text { kerentanan }\end{array}$ \\
\hline & Perlindungan kesehatan kepada Kelompok Rentan \\
\hline & $\begin{array}{l}\text { Pengelolaan SDA dalam rangka pengurangan } \\
\text { Resiko Bencana }\end{array}$ \\
\hline & Perlindungan aset produktif utama masyarakat \\
\hline
\end{tabular}

Sumber : (Badan Nasional Penanggulangan bencana, 2012; Koesuma et al., 2020) 
Tabel 2. Menggambarkan bahwa komponen Desa Tangguh bencana terdiri atas lima dimensi yang terbagi kedalam 18 indikator. Indikator tersebut digunakan sebagai identifikasi upaya untuk mewujudkan ketangguhan masyarakat melalui upaya yang terorganisir dan terstruktur. Peran pemerintah dan pihak non pemerintah dalam program Desa diperlukan namun hanya bersifat sebagai stimulan. Hal tersebut dikarenakan ujung kesuksesan Desa Tangguh Bencana adalah masyarakat itu sendiri. Hal tersebut dikarenakan Desa Tangguh Bencana "dari", "oleh" dan"untuk" masyarakat

Selanjutnya dari indikator pada keempat dimensi diidentifikasi mana sebagai indikator dan sebagai prediktor dalam perspektif reflektif maupun normatif pada ketangguhan masyarakat. Dalam model reflektif diketahui bahwa indikator yang menjadi manifestasi atau petunjuk dari ketangguhan masyarakat sedangkan pada model normatif lebih melihat pada indikator yang mempengaruhi ketangguhan masyarakat.

\section{Tabel 3. Identifikasi aspek Normatif dan Reflektif Desa Tangguh Bencana}

\begin{tabular}{|c|c|c|}
\hline $\begin{array}{c}\text { Normatif } \\
\text { (Pengaruh) }\end{array}$ & Variabel Laten & $\begin{array}{l}\text { Reflektif } \\
\text { (Petunjuk) }\end{array}$ \\
\hline $\begin{array}{l}\text { Pelatihan untuk Tim } \\
\text { relawan; Pelatihan untuk } \\
\text { warga desa; Pelatihan } \\
\text { untuk Pemerintah Desa }\end{array}$ & \multirow{7}{*}{ Ketangguhan Masyarakat } & $\begin{array}{lr}\text { Kebijakan Desa } & \text { Tentang } \\
\text { Pengurangan } & \text { Risiko } \\
\text { Bencana } & \end{array}$ \\
\hline $\begin{array}{l}\text { Pelibatan Perempuan } \\
\text { dalam Tim Relawan }\end{array}$ & & $\begin{array}{l}\text { Forum Pengurangan } \\
\text { Risiko Bencana }\end{array}$ \\
\hline Partisipasi Masyarakat & & Peta dan Analisis Risiko \\
\hline Kerjasama Stakeholder & & $\begin{array}{l}\text { Peta dan Jalur Evakuasi } \\
\text { serta tempat pengungsian }\end{array}$ \\
\hline $\begin{array}{l}\text { Pengelolaan } \text { SDA dalam } \\
\text { rangka } \\
\text { Sistem Risiko Bencana }\end{array}$ & & Sistem Peringatan Dini \\
\hline $\begin{array}{ll}\text { Perlindungan } & \text { aset } \\
\text { produktif masyarakat } & \end{array}$ & & $\begin{array}{l}\text { Ketersediaan dana tanggap } \\
\text { darurat dan Pengurangan } \\
\text { Resiko Bencana }\end{array}$ \\
\hline $\begin{array}{l}\text { Perlindungan kesehatan } \\
\text { kelompok rentan }\end{array}$ & & Mitigasi Struktural \\
\hline
\end{tabular}

Sumber : Analisis Normatif dan Reflective (Bagozzi, 2007; Lindberg \& Swearingen, 2020)

Berdasarkan tabel 3. Menunjukan bahwa aspek pemberdayaan (desa, relawan dan masyarakat), partisipasi masyarakat, kerjasama stakeholder, perlindungan dan pengelolaan terhadap sumber daya komunitas masuk dalam skala normatif yang mana aspek tersebut membangun ketangguhan masyarakat itu sendiri. Aspek tersebut untuk menghasilkan kompetensi masyarakat yang mana 
merupakan bentuk lain dari ketangguhan masyarakat ${ }^{19}$. Dengan kompetensi tersebut akan dapat mengukur sejauh mana komunitas berfungsi dan merespon pada kondisi pra dan pasca bencana terjadi. Selanjutnya aspek lebih lanjut pada skala reflective melihat bagaimana skala normatif ditunjukan, dalam Desa Tangguh Bencana dengan ditunjukan pada berbagai instrumen untuk menghadapi keadaan kahar seperti dengan sistem peringatan dini, kebijakan/regulasi dalam pengurangan resiko bencana, dan mitigasi struktural. Identifikasi dari ketangguhan masyarakat diperlukan untuk mengetahui sejauh mana kontribusi dari faktor yang meningkatkan ketangguhan masyarakat seperti faktor modal sosial, selain sebagai bagian dalam skala normatif dapat berfungsi sebagai pendorong ketangguhan masyarakat dalam menghadapi tantangan eksternal dalam hal ini bencana alam yang tidak dapat diprediksi.

\section{KESIMPULAN}

Desa Tangguh Bencana merupakan penilaian bagaimana melihat ketangguhan masyarakat dalam menghadapi bencana. Ketidakpastian terjadi bencana akibat berbagai faktor eksternal yang akan dihadapi oleh masyarakat menjadikan unsur kesiapsiagaan menjadi faktor utama. Pengembangan Desa Tangguh Bencana sebagai upaya pengurangan risiko sehingga masyarakat akan mampu merespon terhadap perubahan secara dinamis dalam kondisi bencana dan mampu secara mandiri untuk menyelesaikan secara cepat dan tepat sehingga proses pemulihan, pemeliharaan dan penanganannya segera dapat dilakukan. Berdasarkan hasil identifikasi secara normatif dan reflektif akan mampu melihat faktor apa saja dalam indikator Desa Tangguh Bencana sebagai unsur prediktor atau indikator.

Hasil analisa menggambarkan bahwa dimensi dalam Desa Tangguh Bencana masih didominasi pada aspek reflektif. Dominasi terhadap aspek reflektif masih terpusat pada aspek yang bersifat formal sehingga aspek normatif atau faktor pendorong melalui normatif yang seharusnya mampu didorong melalui Desa Tangguh Bencana belum secara maksimal dilakukan. Untuk itu diperlukan pengembangan aspek oleh Desa Tangguh Bencana dalam pendekatan normatif dengan melihat pada aspek - aspek pendukung secara internal dari masyarakat sehingga ketangguhan masyarakat mampu terbentuk. Baik skala formatif dan normatif penting namun diperlukan untuk melihat bagaimana ketangguhan masyarakat dan Desa Tangguh Bencana keterkaitan kedua hal tersebut pada bagaimana interaksi dan keterlibatan individu dan komunitas serta hasil yang dihasilkan sehingga mampu secara maksimal memberdayakan masyarakat.

${ }^{19}$ Sherrieb, K., Norris, F. H., \& Galea, S. (2010). Measuring Capacities for Community Resilience. Social Indicators Research, 99(2), 227-247. https://doi.org/10.1007/s11205-010-9576-9 


\section{DAFTAR PUSTAKA}

Adger, W. N. (2000). Social and ecological resilience: Are they related? Progress in Human Geography, 24(3), 347-364. https://doi.org/10.1191/030913200701540465

Ahmed, R., Seedat, M., Van Niekerk, A., \& Bulbulia, S. (2004). Discerning community resilience in disadvantaged communities in the context of violence and injury prevention. South African Journal of Psychology, 34(3), 386-408. https://doi.org/10.1177/008124630403400304

Badan Nasional Penanggulangan bencana. (2012). Pedoman Umum Desa Tangguh Bencana.

Bagozzi, R. P. (2007). On the Meaning of Formative Measurement and How It Differs From Reflective Measurement: Comment on Howell, Breivik, and Wilcox (2007). Psychological Methods. https://doi.org/10.1037/1082989X.12.2.229

Cutter, S. L., Barnes, L., Berry, M., Burton, C., Evans, E., Tate, E., \& Webb, J. (2008). A place-based model for understanding community resilience to natural disasters. Global Environmental Change, 18(4), 598-606. https://doi.org/10.1016/j.gloenvcha.2008.07.013

Fawcett, S. B., Paine-Andrews, A., Francisco, V. T., Schultz, J. A., Richter, K. P., Lewis, R. K., Williams, E. L., Harris, K. J., Berkley, J. Y., Fisher, J. L., \& Lopez, C. M. (1995). Using empowerment theory in collaborative partnerships for community health and development. American Journal of Community Psychology, 23(5), 677-697. https://doi.org/10.1007/BF02506987

Gamson, W. A., \& Tarrow, S. (1999). Power in Movement: Social Movements and Contentious Politics. Contemporary Sociology. https://doi.org/10.2307/2654187

Koesuma, S., Lelono, S., Muryani, C., \& Legowo, B. (2020). Pembentukan Desa Tangguh Bencana melalui Kuliah Kerja Nyata Tematik Pengurangan Risiko Bencana di Kabupaten Purbalingga. Jurnal Pemberdayaan Masyarakat, 4(1), $42-51$.

Lindberg, K., \& Swearingen, T. (2020). A Reflective Thrive-Oriented Community Resilience Scale. American Journal of Community Psychology, 65(3-4), 467-478. https://doi.org/10.1002/ajcp.12416

Lyth, A. (2015). Community resilience and environmental transitions. In Australasian Journal of Environmental Management (Vol. 22, Issue 3). https://doi.org/10.1080/14486563.2015.1023691

Magis, K. (2010a). Community resilience: An indicator of social sustainability. Society and Natural Resources. https://doi.org/10.1080/08941920903305674

Magis, K. (2010b). Community resilience: An indicator of social sustainability. Society and Natural Resources, 23(5), 401-416. https://doi.org/10.1080/08941920903305674

Morrow, E., \& Scorgie-Porter, L. (2017). Bowling Alone: The Collapse and Revival of American Community. In Bowling Alone: The Collapse and Revival of American Community. https://doi.org/10.4324/9781912282319

Sherrieb, K., Norris, F. H., \& Galea, S. (2010). Measuring Capacities for Community Resilience. Social Indicators Research, 99(2), 227-247. https://doi.org/10.1007/s11205-010-9576-9 
Teitelbaum, L., Ginsburg, M. L., \& Hopkins, R. W. (1991). Cognitive and behavioural impairment among elderly people in institutions providing different levels of care. Cmaj, 144(2), 169-173.

United Nations. (2005). International Strategy for Disaster Reduction Hyogo Framework for Action 2005-2015: Building the Resilience of Nations. World Conference on Disaster Reduction (A/CONF.206/6), 25.

Wee, B. Van, \& Banister, D. (2016). How to Write a Literature Review Paper? Transport Reviews, $36(2)$, 278-288. https://doi.org/10.1080/01441647.2015.1065456

Zautra, A., Hall, J., \& Murray, K. (2008). Community Development and Community Resilience: An Integrative Approach. Community Development, 39(3), 130-147. https://doi.org/10.1080/15575330809489673 